\title{
Enterotoxic effects of Aeromonas sobria haemolysin in a rat jejunal perfusion system identified by specific neutralization with a monoclonal antibody
}

\author{
Sally E. Millership, ${ }^{1 *}$ Michael R. Barer, ${ }^{2}$ R. J. Mulla ${ }^{1}$ and S. ManeCK ${ }^{3}$ \\ ${ }^{1}$ Department of Bacteriology, RPMS, Hammersmith Hospital, Du Cane Road, London WI2 ONN, UK. \\ ${ }^{2}$ Department of Microbiology, The Medical School, Framlington Place, University of Newcastle upon Tyne, UK. \\ ${ }^{3}$ Department of Histopathology, Northwick Park Hospital, Watford Road, Harrow, Middlesex, UK.
}

(Received 15 August 1991; revised 18 October 1991; accepted 31 October 1991)

\begin{abstract}
Investigations into the pathogenesis of Aeromonas diarrhoea have demonstrated that several different cell-free products of motile aeromonads show enterotoxic activity in suckling mouse, rat, and rabbit assay systems. The relative contributions made by separate cytotoxic and cytotonic activities in the mixture produced by in vitro culture remains unresolved. Using a modified rat jejunal perfusion assay, we have studied the effects of $A$. sobria culture filtrates containing defined levels of haemolytic and cytotoxic activity and immunoreactivity for anticholera toxin. This material induced net water, potassium, and sodium loss with a rapid onset $(<5 \mathrm{~min})$ that was readily differentiated from the effects of purified cholera toxin $(>15 \mathrm{~min})$. In filtrates containing up to 128 haemolytic and cytotoxic units of activity, the enterotoxic activity was neutralized by an anti-haemolysin/ cytotoxin monoclonal antibody. No specific histological changes could be found in preparations perfused with enterotoxic material for up to $65 \mathrm{~min}$. These findings indicate that the cytotoxic/haemolytic component of $A$. sobria culture filtrate is the dominant enterotoxic activity.
\end{abstract}

\section{Introduction}

There is evidence that motile Aeromonas spp. are a cause of diarrhoea in humans (Aggar et al., 1985; Gracey et al., 1982; Moyer, 1987). Investigation of the pathogenesis of disease has concentrated on extracellular bacterial products which may have enterotoxic activity. Haemolysin production in vitro is common among strains of Aeromonas sobria and Aeromonas hydrophila, but not Aeromonas caviae (Barer et al., 1986; Brenden \& Janda, 1987). The species sobria and hydrophila are associated with diarrhoea, whereas caviae may not be (Burke et al., 1983; Millership et al., 1986). Purified haemolysin has cytotoxic activity in cell cultures and enterotoxic activity in rabbits and mice (Asao et al., 1984; Potomski et al., $1987 a$ ). However, enterotoxic activity is only manifest at 5-30 times the protein concentration of other enterotoxins active in suckling mice (Potomski et al., 1987a) which suggests this may not be its natural role.

Cytotonic activity with effects similar to cholera toxin in cell monolayer cultures has been distinguished from haemolysin by its stability at $56{ }^{\circ} \mathrm{C}$ (Ljungh \& Kronevi,

*Author for correspondence: Tel: (081) 7403224; fax (081) 7492281.
1982). There have also been a number of reports of crossreactions of Aeromonas culture filtrates with polyclonal anti-cholera toxin antibodies (Potomski et al., 1987b; Schultz \& McCardell, 1988). Cytotonin purified by affinity to polyclonal anti-cholera toxin has enterotoxic activity; however, cholera toxin-like activity was detected by ELISA in approximately $25 \%$ of strains from all species and was not necessarily associated with diarrhoea (Potomski et al., 1987b).

Howard \& Buckley (1985) have shown that $A$. hydrophila haemolysin is produced as a precursor which is cleaved by protease to form active toxin. Cytotoxin and cytotonin are often present together in culture filtrates (Potomski et al., 1987a) and it is possible that one toxin potentiates the effect of the other, as is the case with Clostridium difficile toxins A and B (Lyerly et al., 1988). It is thus important to study the combined effects of cell-free products of bacterial growth in concentrations the bacterium is capable of producing.

The present report examines the hypothesis that haemolysin present in culture supernatant of $A$. sobria, as well as being a cytotoxin, is also the dominant enterotoxin present. A modified rat jejunal perfusion assay was used because it allows study of the time course 
of water and ion fluxes in the gut and because it is known to respond to other cytotoxic and cytotonic enterotoxins (Thelen et al., 1978; Harley et al., 1986).

\section{Methods}

Bacterial strains. A clinical isolate of $A$. sobria $\left(27 \mathrm{P}^{+}\right)$from a patient with diarrhoea was used as a source of culture filtrate. No other infectious cause for his diarrhoea was identified. Culture filtrate from this strain produced both cytotoxic and cytotonic effects in $\mathrm{Y} 1$ adrenal and Vero cell monolayers and also in lysed rabbit erythrocytes. Two strains were used as haemolysin negative controls. One was a mutant of the wild-type $A$. sobria $\left(27 \mathrm{P}^{-}\right)$, selected for its inability to produce protease on milk agar and unable to produce haemolysin under the culture conditions used. The mutant was produced by incubation of the centrifuged deposit from an overnight broth culture of strain $27 \mathrm{P}^{+}$with 4-nitroquinoline-1-oxide $\left(0.1 \mathrm{mg} \mathrm{ml}^{-1}\right.$ in PBS) for $2 \mathrm{~h}$ at $37^{\circ} \mathrm{C}$, after incubation for $1 \mathrm{~h}$ in PBS alone. The reaction was terminated by tenfold dilution and addition of $5 \%(\mathrm{w} / \mathrm{v})$ sodium thiosulphate. The second negative control strain was an $A$. caviae (strain 3) from the faeces of a healthy 2-year-old child.

Preparation of bacterial culture filtrates. Bacterial strains were stored at $-70{ }^{\circ} \mathrm{C}$ in nutrient broth with $20 \%(\mathrm{v} / \mathrm{v})$ glycerol. They were thawed and subcultured on horse blood agar. After overnight incubation at $37^{\circ} \mathrm{C}$, a sweep was used to inoculate $20 \mathrm{ml}$ nutrient broth. This was incubated for $6 \mathrm{~h}$ at $37^{\circ} \mathrm{C}$, then added to $50 \mathrm{ml}$ or $100 \mathrm{ml}$ tryptone soy broth (Oxoid) with $0.6 \%$ yeast extract (Oxoid) (TSBYE) in $250 \mathrm{ml}$ flasks. Flasks were incubated for $14 \mathrm{~h}$ overnight at $37^{\circ} \mathrm{C}$ with shaking at 100-200 r.p.m.

Culture supernatants were harvested by centrifugation, then filtered through a $0.45 \mu \mathrm{m}$ membrane, and dialysed overnight at $4{ }^{\circ} \mathrm{C}$ against an isotonic buffer comprising $0.13 \mathrm{M}-\mathrm{NaCl}, 4 \mathrm{mM}-\mathrm{KCl}, 0.025 \mathrm{M}-\mathrm{NaHCO}_{3}$, $2 \mathrm{~mm}$-glucose and $15 \mathrm{~g}$ polyethylene glycol 4000 in sterile deionized water at $\mathrm{pH} 7.3$ (dialysis buffer). Where necessary dialysed filtrates were further diluted in dialysis buffer to reduce toxin titres and the titres rechecked. In rat experiments, $4 \mathrm{mg}$ phenol red $\mathrm{l}^{-1}$ (Sigma) was added as a marker of dilution or concentration of the intraluminal fluid. In dose-response and antibody experiments culture filtrate was stored at $-20^{\circ} \mathrm{C}$ until dialysis, otherwise filtrates were dialysed and used within $24 \mathrm{~h}$.

Production of monoclonal antibody. A murine monoclonal antibody (F12) was selected by its ability to neutralize cytotoxic activity of $27 \mathrm{P}^{+}$ culture (filtrate applied directly to the hybridoma cell line). This IgG1 antibody bound to a major polypeptide band of $50 \mathrm{kDa}$ in strain $27 \mathrm{P}^{+}$ supernatants, and neutralized cytotoxic and haemolytic activity in a manner consistent with the view that binding of the polypeptide to target cells is inhibited (Barer \& Millership, 1990). It was purified using protein A bound to Protrans discs (ICN Biomedicals). Binding buffer was $1.5 \mathrm{M}$-glycine, $3 \mathrm{M}-\mathrm{NaCl}$ adjusted to $\mathrm{pH} 8.9$. Crude hybridoma supernatant was diluted $1: 2$ in binding buffer and recirculated through the disc at a rate of $6 \mathrm{ml} \mathrm{min}^{-1}$ for at least two passes. Antibody was eluted with $100 \mathrm{~mm}$-citric acid adjusted to $\mathrm{pH} 6.0$ with $5 \mathrm{M}-\mathrm{NaOH}$. Discs were regenerated with $100 \mathrm{~mm}$-citric acid at $\mathrm{pH} 3.0$. The purified antibody was washed and concentrated in phosphate buffered saline, $\left(0.14 \mathrm{M}-\mathrm{NaCl}, 2.7 \mathrm{~mm}-\mathrm{KCl} \quad 8.1 \mathrm{~mm}-\mathrm{Na}_{2} \mathrm{HPO}_{4}, \quad 1.47 \mathrm{mM}-\mathrm{KH}_{2} \mathrm{PO}_{4}\right.$ pH 7.4) (PBS) using Amicon Centriprep 30000 concentrators, to $0 \cdot 18 \mathrm{mg} \mathrm{ml}^{-1}$. Protein concentration was measured spectrophotometrically at $280 \mathrm{~nm}$.

Haemolysin assay. Haemolysin was assayed using rabbit red cells up to $24 \mathrm{~h}$ old collected in Alsever's solution (0.114 M-dextrose, $0.027 \mathrm{M}$ trisodium citrate dihydrate, $0.072 \mathrm{M}-\mathrm{NaCl}$ ). The assay was performed as described by Burke et al. (1981). Titres were read visually, and haemolysin units (HU) quoted as the reciprocal of the final dilution of culture filtrate in the last well showing $>90 \%$ haemolysis.

In neutralization assays with purified monoclonal antibody an equal volume of monoclonal antibody or PBS was added to each well of a twofold serial dilution of culture filtrate in a microtitre tray, and incubated for $30 \mathrm{~min}$ at $37^{\circ} \mathrm{C}$. Two vols $1 \%$ red cells were then added and the assay completed as before.

Cytotoxin assays. These were performed as previously described (Barer et al., 1986) in Vero cell monolayers. Cytotoxin units (CU) were read after $18 \mathrm{~h}$ as the reciprocal of the final dilution of bacterial culture filtrate in the last well showing $>90 \%$ destruction of the cell monolayer. Twofold serial dilutions of cholera toxin (Sigma) (100 ng $\mathrm{ml}^{-1}$ in medium 199) were used as a cytotonin control, and titres were read as the last well showing $>90 \%$ cell rounding.

In neutralization assays with purified monoclonal antibody, one vol. undiluted antibody or medium 199 was added to one vol. of twofold serial dilution of dialysed bacterial culture filtrate, and incubated at $37^{\circ} \mathrm{C}$ for $30 \mathrm{~min}$. After inoculation, $0.05 \mathrm{ml}$ of the antibody/culture filtrate or medium 199/culture filtrate mixture was added to wells of the microtitre tray, and the assay completed as before.

Immunoblotting. Dot-blots and Western blots were performed by standard techniques using filtered culture supernatants as a source of antigen. For dot-blot assays, uninoculated TSBYE was used as a negative control, and commercial cholera toxin (Sigma) at concentrations of 2,5,10 and $20 \mu \mathrm{g} \mathrm{ml}^{-1}$ as positive controls. In blocking assays, rabbit antiserum was pre-adsorbed with cholera toxin by initial dilution 1 in 2 with cholera toxin solution $\left(1 \mathrm{mg} \mathrm{ml}^{-1}\right)$. For Western blots, SDS-PAGE was performed by the method of Laemmli (1970), with $3 \%(w / v)$ acrylamide in the stacking gel and $12.5 \%(w / v)$ acrylamide in the resolving gel. Electrophoresis was performed at a constant current of $14 \mathrm{~mA}$ for the stacking gel and $20 \mathrm{~mA}$ for the resolving gel. The gel was blotted overnight by capillary diffusion onto a $0.45 \mu \mathrm{m}$ nitrocellulose membrane (Sigma).

Cholera-toxin-like antigen was detected in blots by incubation with rabbit anti-cholera toxin antibody (kindly supplied by Dr B. Drasar, London School of Hygiene and Tropical Medicine), diluted 1:25 in $0.05 \%$ fat-free milk powder. Incubation was for $2 \mathrm{~h}$ in Tris-buffered saline. Bound antibody was visualized using biotinylated donkey antirabbit antibody (Amersham), streptavidin horse-radish peroxidase complex (Amersham) and 4-chloro-1-naphthol (Sigma), in sequence.

Rat jejunal perfusion assay. The method was based on that of Thelen et al. (1978), although younger animals were used. Female Wistar rats weighing $100 \mathrm{~g}$ were starved overnight, anaesthetized with $60 \mathrm{mg} \mathrm{kg}^{-1}$ thiopentone sodium and maintained at a rectal temp of $37^{\circ} \mathrm{C}$ on a thermostatically controlled blanket. A $20-30 \mathrm{~cm}$ length of jejunum was isolated, and cannulated at both ends. At the end of the experiment the length of bowel perfused was measured. Perfusion fluids were prewarmed to $37^{\circ} \mathrm{C}$ in a water bath and perfused at approximately $20 \mathrm{ml} \mathrm{h}^{-1}$. Perfusion was begun with dialysis buffer, or in some experiments bacterial culture filtrate with monoclonal antibody, for $30-40 \mathrm{~min}$, then changed to a second fluid. In this way animals acted as their own controls. In experiments to determine the ability of the gut to recover from the effects of toxin, perfusion was completed with dialysis buffer as the third perfusion fluid. Samples of perfusion fluids and perfusates, collected in $10 \mathrm{~min}$ fractions, were filtered through a $0.45 \mu \mathrm{m}$ pore size filter. Water flux was then assessed by measuring the relative dilution or concentration of the phenol red marker by adding $1 \mathrm{ml} 0.2 \mathrm{M}-\mathrm{NaOH}$ to a $0.2 \mathrm{ml}$ sample and measuring the $\mathrm{OD}_{560}$ of the alkalinized samples against a blank of dialysed perfusion solutions to which phenol red had not been added. Water flux was calculated according to the formula:

$$
\begin{aligned}
& \left(\mathrm{OD}_{\text {in }} / \mathrm{OD}_{\text {out }}-1\right) \times \text { perfusion rate }(\mu \mathrm{l} \mathrm{h}-1) / \text { gut length }(\mathrm{cm}) \\
& =\text { water flux }\left(\mu \mathrm{cm}^{-1} \mathrm{~h}^{-1}\right)
\end{aligned}
$$


where $O D_{\text {in }}$ is the optical density of the perfusion fluid and $O D_{\text {out }}$ is the optical density of the perfusate collected.

Ion fluxes were calculated in similar fashion:

$$
\begin{aligned}
& \text { [(Ion } \left.\left.{ }_{\text {in }}-\text { Ion }_{\text {out }}\right) \times \text { perfusion rate/gut length }\right]-\left(\text { Ion }_{\text {out }} \times \text { water flux }\right) \\
& \quad=\operatorname{Ion}_{\text {flux }}
\end{aligned}
$$

where $\operatorname{Ion}_{\text {in }}$ is the ion concentration $\left(\mu \mathrm{mol} 1^{-1}\right)$ of the perfusion fluid and Ion $_{\text {out }}$ is the ion concentration of the perfusate collected. Ion concentrations were measured in a Beckman E2A analyser (indirect ion selective electrodes).

Cholera toxin (Sigma) was reconstituted in distilled water, then diluted in dialysis buffer to a concentration of $100 \mathrm{ng} \mathrm{ml}^{-1}$. Phenol red $\left(4 \mathrm{mg} \mathrm{l}^{-1}\right)$ was added as a marker.

Differences in fluxes were calculated from the difference between the mean of fluxes at $-20,-10$ and 0 min pre-perfusion with test solution, and at $+10,+20+30$ min post-perfusion. In the case of cholera toxin, post perfusion values were calculated from the time of onset of loss of water in the gut.

Where required, monoclonal antibody preparations were mixed with bacterial culture filtrate $30 \mathrm{~min}$ before perfusion. In all experiments with antibody, a single aliquot of bacterial culture filtrate was divided between control animals perfused with filtrate and test animals perfused with the antibody culture filtrate mixture. In experiments with crude antibody, bacterial culture filtrate was diluted in hybridoma culture supernatant for the test, with dilution in hybridoma growth medium (RPMI 1640 with $20 \%$ foetal calf serum) as a control. Purified monoclonal antibody was diluted in bacterial culture filtrate for the test, with PBS added to the culture filtrate as a control perfusion solution.

Histology. At the end of the experiment segments of perfused gut, up to $3 \mathrm{~cm}$ in length, were excised prior to animal sacrifice. These were fixed in $10 \%(\mathrm{v} / \mathrm{v})$ formalin before paraffin embedding. Sections of fixed tissue were stained with haematoxylin and eosin for histological examination. Light microscopy was initially carried out blindly, all observed changes being compared to a normal section of rat jejunum. The parameters that were studied included architecture, mucosal thickness, oedema, congestion, haemorrhage, inflammation, ulceration, necrosis, brush border and goblet cell morphology.

\section{Results}

Relationship between haemolytic, cytotoxic and enterotoxic activity.

Seven control rat preparations perfused with haemolysinand cytotoxin-negative solutions were examined. These included two where perfusion with $27 \mathrm{P}^{-}$was preceded or followed by buffer, two with buffer alone and three with strain 3 alone. In all cases, water absorption continued essentially unchanged at a baseline varying between 50 and $150 \mu \mathrm{cm}^{-1} \mathrm{~h}^{-1}$ in different animals for up to $110 \mathrm{~min}$.

Culture filtrate from strain $27 \mathrm{P}^{+}$caused an almost immediate net loss of water, sodium and potassium into the gut lumen. An example of the results obtained (8 rats) is shown in Fig. 1.

One pooled culture filtrate with $2048 \mathrm{CU}$ and 2048 HU was used in all subsequent experiments.

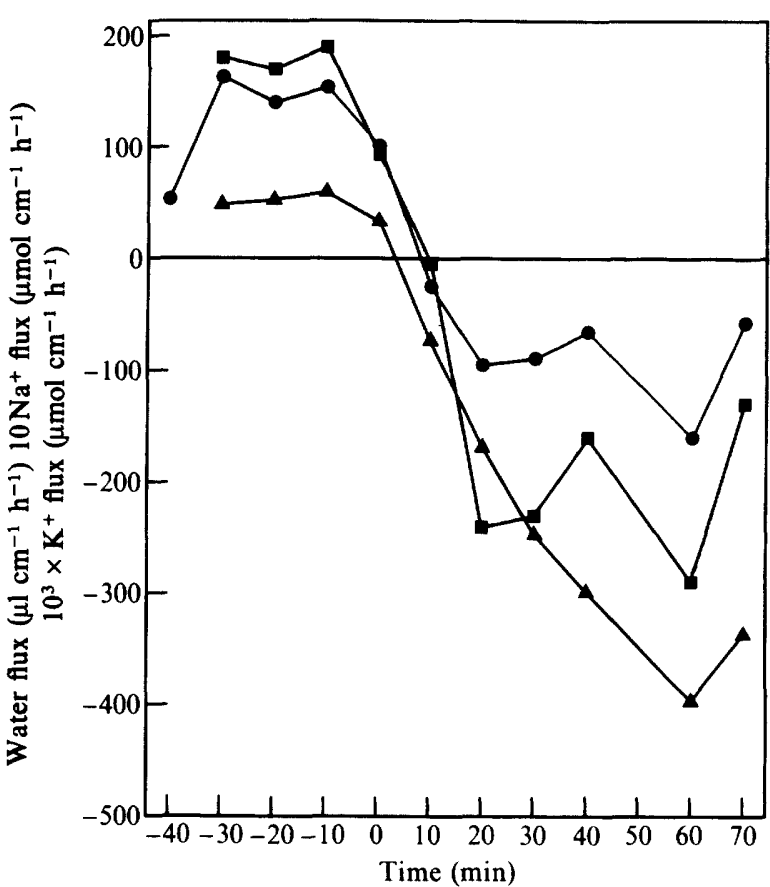

Fig. 1. Effects of haemolytic culture filtrate in the rat jejunum. A representative set of results are shown from one experiment. Perfusion began with non-haemolytic culture filtrate from strain 3 , followed at time 0 by filtrate from strain $27 \mathrm{P}^{+}$. A negative flux indicates secretion into the gut lumen. Symbols: $\bigcirc$, water; $\square, \mathrm{Na}^{+} ; \boldsymbol{\Delta}, \mathrm{K}^{+}$.

Haemolytic and cytotoxic titres of culture filtrate were identical in pre- and post-dialysis samples. A single freeze and thaw had no effect on the titres. Serial dilution showed a dose-response relationship for the difference between mean water flux during perfusion with buffer and perfusion with culture filtrate (Fig. 2). The correlation coefficient for points between 102 and $256 \mathrm{HU}$ (the linear portion of an apparent sigmoid relationship) was 0.774 . The change in mean sodium and potassium fluxes before and after perfusion with culture filtrate showed a corresponding decrease with decreasing haemolysin and cytotoxin titres. Dilution was accompanied by equivalent serial reductions in cytotoxin and haemolysin titres. Short perfusion times of $20-30 \mathrm{~min}$ were sufficient to cause secretion even when the culture filtrate was diluted to $128 \mathrm{CU} / 128 \mathrm{HU}$. When culture filtrate was replaced by dialysis buffer a return to water absorption occurred within $20-30 \mathrm{~min}$. The time of onset of secretion and time to recovery was unchanged in different dilutions of culture filtrate. Culture filtrate heated at $56^{\circ} \mathrm{C}$ for $10 \mathrm{~min}$ became haemolysin- and cytotoxin-negative, and lost enterotoxic activity in the perfusion assay.

\section{Effect of antihaemolysin monoclonal antibody.}

A culture filtrate of strain $27 \mathrm{P}^{+}$with $2048 \mathrm{HU}$ and 2048 $\mathrm{CU}$ was used in these experiments. The purified 


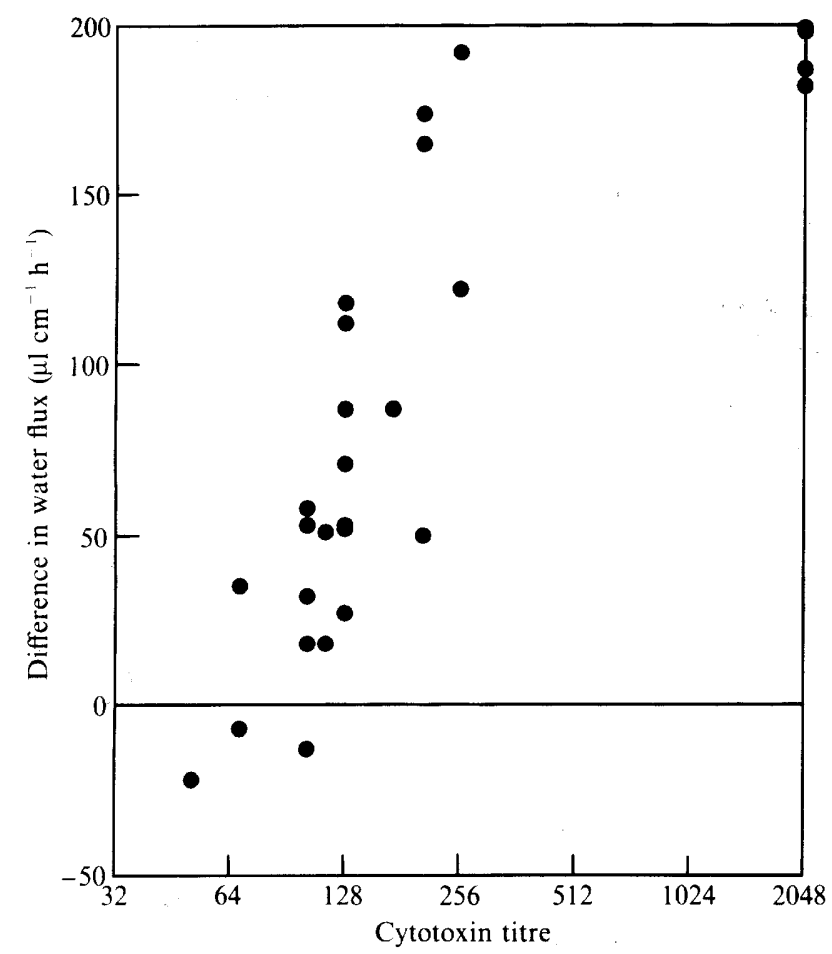

Fig. 2. Dose-response relation for haemolytic culture filtrate in the rat jejunum. Each point represents the difference between mean water flux during perfusion with dialysis buffer and culture filtrate from strain $27 \mathrm{P}^{+}$for one rat. A positive difference indicates decreased absorption or increased water loss into the gut on introduction of $27 \mathrm{P}^{+}$culture filtrate.

monoclonal antibody preparation neutralized the haemolysin activity of an equal volume of a 1 in 4 dilution of culture filtrate and the cytotoxin activity of an equal volume of a 1 in 8 dilution of culture filtrate. This antibody preparation therefore had 512 neutralizing units of haemolytic activity (NHU) and 256 neutralizing units of cytotoxin activity (NCU).

In order to conserve antibody and achieve complete neutralization of haemolytic activity, the $2048 \mathrm{HU} / \mathrm{CU}$ culture filtrate was diluted 16-fold in dialysis buffer ( 5 rats) or hybridoma growth medium (2 rats) as positive controls for neutralization with purified or crude antibody, respectively. In each case, a loss of water into the gut lumen was induced. Addition of purified antibody (128 NHU/64 NCU) to the corresponding dilutions of culture filtrate ( 3 rats) or dilution of culture filtrate in crude hybridoma growth medium (2 rats) failed to elicit water loss. Changes in water flux with nonhaemolytic, $128 \mathrm{HU} / \mathrm{CU}$ culture filtrate and $128 \mathrm{HU} / \mathrm{CU}$ culture filtrate plus antibody are shown in Fig. 3. Changes in sodium and potassium flux were also inhibited in the presence of antibody (not shown).

Perfusion with culture filtrate plus crude antibody for 30-40 min, followed by culture filtrate alone, showed

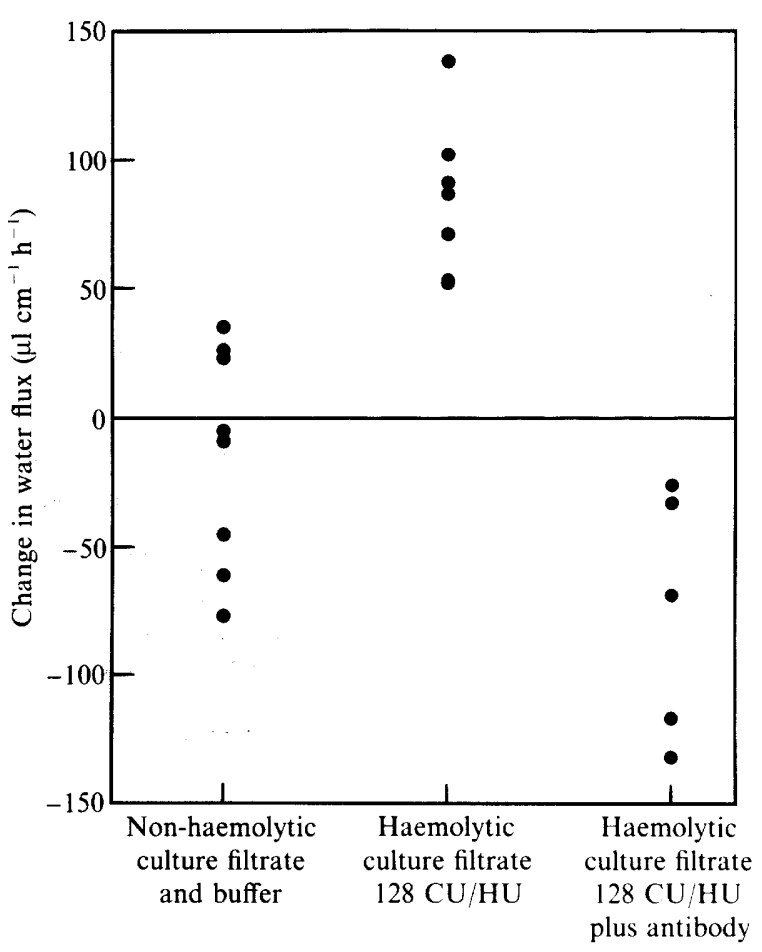

Fig. 3. Effect of monoclonal antibody on water flux in the rat jejunum. Each point represents the difference between mean water flux during perfusion with dialysis buffer and bacterial culture filtrate, or in the case of continued perfusion with dialysis buffer, mean fluxes at the beginning and end of perfusion. Results for perfusion with nonhaemolytic culture filtrates from $A$. sobria strain $27 \mathrm{P}^{-} A$. caviae strain 3 and continued dialysis buffer have been combined. Results of the effects of pure and crude antibody have also been combined. A positive difference indicates decreased water absorption or increased water loss into the gut lumen on introduction of bacterial culture filtrate.

initial water absorption, then an immediate change to water loss when culture filtrate was introduced.

\section{Investigation of cholera-toxin-related and cytotonic activities.}

Culture filtrates from strains 3 and $27 \mathrm{P}^{+}$both showed reactivity with anti-cholera toxin in the range equivalent to $2-5 \mu \mathrm{g} \mathrm{ml}^{-1}$ of CT by dot-blot assay. The reaction was blocked by prior adsorption of the rabbit anti-serum with cholera toxin. A Western blot of filtrate from $27 \mathrm{P}^{+}$ showed reactivity with a major band at $61 \mathrm{kDa}$ and two minor bands at 44.5 and $32.5 \mathrm{kDa}$. These were quite distinct from the reactivity shown by anti-haemolysin monoclonal antibody to the same culture filtrate. Filtrate from strain 3 showed three closely spaced bands in the region of $61 \mathrm{kDa}$ and cholera toxin itself bands at 23 and $11.7 \mathrm{kDa}$. Fourteen additional strains $(5 \mathrm{~A}$. caviae, $5 \mathrm{~A}$. hydrophila, $4 A$. sobria) were examined by dot-blotting with anti-CT antibody. Four showed no reactivity ( $2 A$. caviae, $2 A$. hydrophila), 8 showed reactivity in the range 


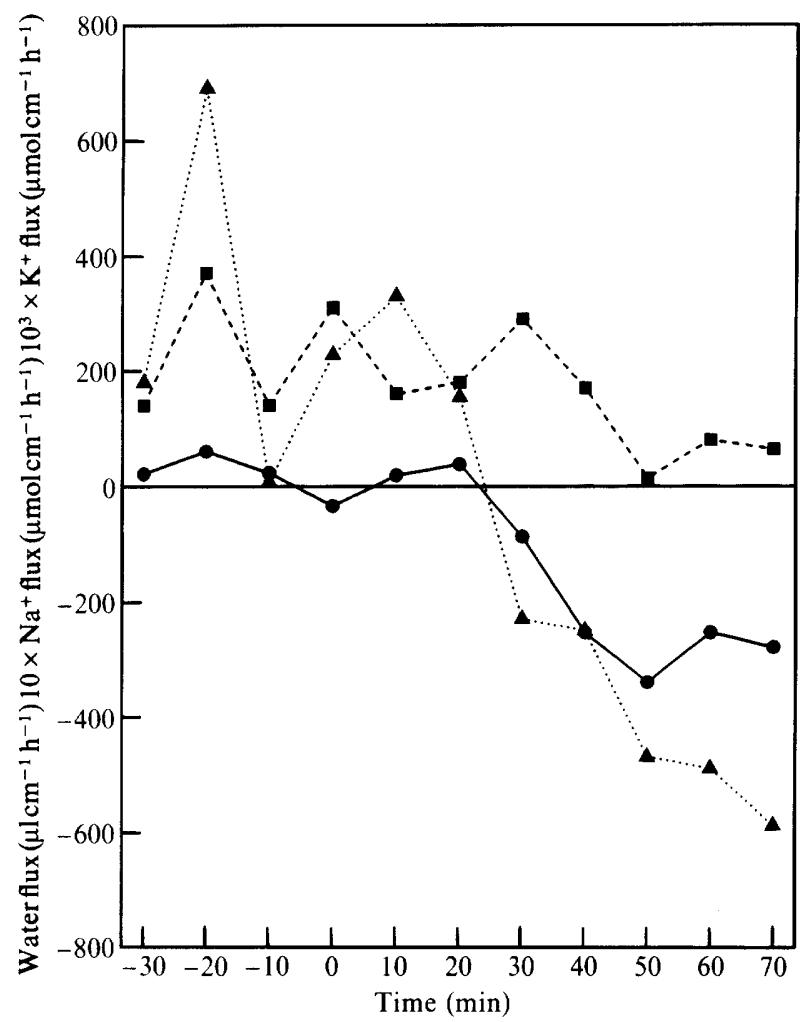

Fig. 4. Effect of cholera toxin on water, $\mathrm{Na}^{+}$and $\mathrm{K}^{+}$fluxes in the rat jejunum. A representative experiment on one rat is shown. The rat was perfused with dialysis buffer changed at time 0 to $100 \mathrm{ng}$ cholera toxin $\mathrm{ml}^{-1}$ diluted in dialysis buffer. A negative flux indicates secretion into the gut lumen. Symbols: $\mathbf{O}$, water; $\mathbf{\square}, \mathrm{Na}^{+} ; \mathbf{\Delta}, \mathrm{K}^{+}$.

$2-5 \mu \mathrm{g} \mathrm{ml}^{-1}$ and 2 , reactivity $>5 \mu \mathrm{g} \mathrm{ml}^{-1}$. All of these filtrates, except those prepared from the 5 strains of $A$. caviae, showed haemolytic and cytotoxic activity.

Cytotonic activity was not reproducibly demonstrable in $27 \mathrm{P}^{+}$preparations applied to Vero cells. Effects reminiscent of those seen with cholera toxin were sometimes seen in heat-treated $\left(56^{\circ} \mathrm{C}, 30 \mathrm{~min}\right)$ preparations. In previous studies (Barer et al., 1986) material from $27 \mathrm{P}^{+}$had also failed to produce consistent cytotonic effects when applied to Y-1 and CHO cells.

In each of three rats perfused with cholera toxin for at least $30 \mathrm{~min}$, after a delay of $20-30 \mathrm{~min}$ there was a marked change from water absorption to water secretion into the gut lumen (Fig. 4). There was an accompanying loss of sodium and potassium but the time course and pattern of the response was quite distinct from that seen with $27 \mathrm{P}^{+}$filtrates. Short perfusion times of $20 \mathrm{~min}$ in 4 animals did not cause secretion of water, even at a concentration of $10 \mu \mathrm{g} \mathrm{ml}^{-1}$.

\section{Histology.}

Sections of jejunum from 20 rats were examined including those perfused with buffer (2), cholera toxin
(2), culture filtrate from $A$. caviae (1), neat (6), dilute (3) and heated filtrate (2) from $A$. sobria and filtrate from $A$. sobria in the presence of anti-haemolysin antibody (4). Neat $A$. sobria culture filtrate was perfused for up to $65 \mathrm{~min}$. There were no striking pathological changes in any of the specimens. A minor to mild degree of mucosal and submucosal oedema was noted in several cases, which included cholera toxin, $A$. sobria culture filtrate both neat and dilute, and in the presence of antihaemolysin antibody. There was focal minor villous surface unregularity, particularly at the tips in some specimens from rats perfused with cholera toxin, or neat and dilute $\boldsymbol{A}$. sobria filtrate. However, three rats perfused with neat $A$. sobria culture filtrate did not show any abnormality. No morphological changes could be ascribed to any particular perfusion solution.

\section{Discussion}

Rat jejunal perfusion systems have been used before to study bacterial enterotoxins and other secretagogues (Sladen \& Harries, 1972; Thelen et al., 1978; Harley et al., 1986; Sagher et al., 1990; Young et al., 1990). In contrast to the rabbit ileal loop and suckling mouse assays, perfusion studies allow investigation of the time course of changes in water and ion fluxes, which, as shown here, can be used to distinguish the effects of different toxins. We have modified the technique to allow each animal to act as its own control, thus reducing the number of animals required and allowing precise determination of the time course of enterotoxic activity.

Haemolytic culture filtrate from a strain of $A$. sobria caused the immediate onset of secretion of water, $\mathrm{Na}^{+}$ and $\mathrm{K}^{+}$ions into the gut lumen. The effect was maximal at a haemolytic and cytotoxic titre of 256, and undetectable at haemolytic and cytotoxic titres of less than 64. Short perfusion times of $20-30 \mathrm{~min}$ were sufficient to cause reversible water and ion loss.

The haemolysin is probably a cytotoxin in cell culture (Asao et al., 1984; Potomski et al., 1987a) but there was no histological evidence that mucosal cell destruction contributed to the enterotoxic effects of haemolytic culture filtrate. These effects are clearly reversible, which also argues against major cell damage as a mechanism for initial enterotoxic activity. We could find no evidence of haemorrhagic enteritis in association with haemolytic culture filtrates (Ljungh \& Kronevi, 1982).

Haemolytic, cytotoxic and enterotoxic activities of $A$. sobria culture filtrate were all abolished by heating at $56{ }^{\circ} \mathrm{C}$ for $10 \mathrm{~min}$ and significantly reduced in the presence of monoclonal antibody. The latter reacted strongly with a band of $50 \mathrm{kDa}$ in a Western blot against extracellular proteins (Barer \& Millership, 1990), which 
is consistent with the reported molecular mass of purified haemolysin (Asao et al., 1984; Howard \& Buckley, 1985). It is therefore likely that the effects on water and ion exchange in the rat gut were caused by haemolysin present in Aeromonas culture filtrate.

There was little relationship between responses elicited by $A$. sobria culture filtrate and cholera toxin. The time of onset of cholera toxin activity was delayed 20 $30 \mathrm{~min}$, whereas that of $A$. sobria culture filtrate was virtually immediate. A short perfusion time with dilute $A$. sobria culture filtrate provoked secretion, whereas cholera toxin even at 100 times the concentration normally employed, did not provoke secretion unless perfusion continued for more than $30 \mathrm{~min}$. These levels of cholera toxin were in excess of the level of cholera toxin immunoreactivity found in our $27 \mathrm{P}^{+}$perfusion preparation, which suggests that cholera-toxin-like activity was not a significant component of the enterotoxic effects observed here. Changes in ion fluxes were similar, although cholera toxin caused less potassium loss for an equivalent change in sodium flux as compared to $A$. sobria culture filtrate.

Although cholera-toxin-like immunoreactivity was present in both haemolysin-positive and -negative culture filtrates from Aeromonas strains we have not found evidence that this was related to enterotoxicity in our assay. Fresh culture filtrate from a strain of $\boldsymbol{A}$. caviae with cholera-toxin-like, but not haemolysin activity perfused in the rat jejunum was not different in effect from dialysis buffer. The level of toxin detected was at least 10 times that required for the activity of pure cholera toxin. In Vero cell monolayers, effects similar to that of cholera toxin could be seen after dialysis of haemolysin-positive culture filtrate. However, these were probably related to the presence of haemolysin/ cytotoxin. Titres were identical to those of cytotoxin predialysis, and a monoclonal antibody raised against cytotoxin neutralized haemolysin and the cytotonic effects of dialysed culture filtrate on Vero cell monolayers. We were unable to detect reproducibly the cytotonic effects in undialysed filtrates which we have previously noted (Barer et al., 1986).

Other authors (Potomski et al., 1986b) have found that polyclonal anti-cholera toxin reacts with four major bands in Aeromonas culture filtrate. The reported molecular masses on a Western blot were $150,43 \cdot 5,29 \cdot 5$ and $27 \mathrm{kDa}$, as against three bands of $61,44.5$ and $32.5 \mathrm{kDa}$ in our study. The reasons for these differences are not clear. The molecular masses of these bands were quite different from those of haemolysin and cholera toxin, although adsorption of the rabbit antiserum suggested that they share some antibody binding sites with cholera toxin.

In conclusion, these results support the notion that in the complex mixture of proteins present in an $A$. sobria culture filtrate, haemolysin is an active enterotoxin by a mechanism which is not dependent upon gross cell disruption. Although immunologically reactive choleratoxin-like activity was present, this did not appear to have any effect on the rat jejunal perfusion system. This is in accord with the clinical finding that production of haemolysin, rather than cytotonin or CT immunoreactivity, is related to isolation of strains from patients with diarrhoea (Moyer, 1987).

This work was partly supported by a grant from the Nuffield Foundation, London, UK. S. Millership was also in receipt of the Gillson Scholarship, The Society of Apothecaries of London, UK. We thank Andrew Tomkins, Vicky Harley and Alison Clegg for their help in establishing the rat perfusion assay. Cell culture facilities in Newcastle were supported by the Lord Dowding Trust for Humane Research.

\section{References}

AgGar, W. A., McCormick, J. D. \& GURWITH, M. J. (1985). Clinical and microbiological features of Aeromonas hydrophila-associated diarrhea. Journal of Clinical Microbiology 21, 909-911.

asao. T., Kinoshita, Y., Kozaki, S., Uemura, T. \& Sakaguchi, G. (1984). Purification and some properties of Aeromonas hydrophila hemolysin. Infection and Immunity 46, 122-127.

BARER, M. R. \& MillershiP, S. E. (1990). Direct selection of monoclonal antibodies neutralising the cytotoxic activity of Aeromonas sobria. FEMS Microbiology Letters 71, 311-314.

Barer, M. R., Millership, S. E. \& TABaqchali, S. (1986). Relationship of toxin production to species in the genus Aeromonas Journal of Medical Microbiology 22, 303-309.

BRENDEN, R. \& JANDA, M. (1987). Detection, quantitation and stability of the B haemolysin of Aeromonas spp. Journal of Medical Microbiology 24, 247-251.

Burke, V., Robinson, J., AtKinson, H. M., Dibley, M., Berry, R. J. \& GRACEY, M. (1981). Exotoxins of Aeromonas hydrophila. Australian Journal of Experimental Biology and Medical Science 59, 753-761.

Burke, V., Robinson, J., Beaman, J., Grace, M., Lesmana, M., ROCKHILL, P., ECHEVERRIA, P. \& JANDA, J. M. (1983). Correlation of enterotoxicity with biotype in Aeromonas spp. Journal of Clinical Microbiology 18, 1196-1200.

Gracey, M., BURKe, V. \& Robinson, J. (1982). Aeromonas-associated gastroenteritis. The Lancet ii, 1304-1306.

Harley, V., Clegg, A., Tranter, H. S., Drasar, B. S., Ellis, D., TOREY, G. \& TOMKINS, A. M. (1986). Clostridium perfringens enterotoxin: physiological response and neutralisation by monoclonal antibody. Biochemical Society Transactions 14, 1083-1084.

HowARD, S. P. \& BUCKLEY, J. T. (1985). Activation of the hole-forming toxin aerolysin by extracellular processing. Journal of Bacteriology 163, 336-340.

LAEMMLI, U. K. (1970). Cleavage of structural proteins during the assembly of the head of bacteriophage T4. Nature, London 227, 680-685.

LJUNGH, A. \& KRONEVI, T. (1982). Aeromonas hydrophila toxinsintestinal fluid accumulation and mucosal injury in animal models. Toxicon 20, 397-407.

LyerLy, D. M., KRIVAN, H. C. \& Wilkins, T. D. (1988). Clostridium difficile: its disease and toxins. Clinical Microbiology Reviews 1, 1-18.

Millership, S. E., BareR, M. R. \& TabaQchali, S. (1986). Toxin production by Aeromonas spp, from different sources. Journal of Medical Microbiology 22, 311-314.

MOYER, N. P. (1987). Clinical significance of Aeromonas species isolated from patients with diarrhea. Journal of Clinical Microbiology 25, 2044-2048. 
Potomski, J., Burke, V., Watson, I. \& Gracey, M. (1987a). Purification of cytotoxic enterotoxin of Aeromonas sobria by use of monoclonal antibodies. Journal of Medical Microbiology 23, 171-177.

Potomski, J., Burke, V., Robinson, J., Fumarola, D. \& MiragLIOTTA, G. (1987b). Aeromonas cytotonic enterotoxin cross-reactive with cholera toxin. Journal of Medical Microbiology 23, 179-186.

Sagher, F. A., Dodge, J. A., Moor, R., McMaster, C. \& MCCaughey, G. (1990). Modulation of fluid absorption and the secretory response of rat jejunum to cholera toxin by dietary fat. Gut 31, 1256-1261.

Schultz, A. J. \& McCardell, B. A. (1988). DNA homology and immunological cross-reactivity between Aeromonas hydrophila cyto- tonic toxin and cholera toxin. Journal of Clinical Microbiology 26, 57-61.

Sladen, G. E. \& Harries, J. T. (1972). Studies on the effects of unconjugated dihydroxy bile salts on rat small intestinal function in vivo. Biochimica et Biophysica Acta 288, 443-456.

Thelen, P., Burke, V. \& Gracey, M. (1978). Effects of intestinal micro-organisms on fluid and electrolyte transport in the jejunum of the rat. Journal of Medical Microbiology 11, 463-470.

Young, A. \& Levin, R. J. (1990). Diarrhoea of famine and malnutrition; investigations using a rat model 1 . Jejunal hypersecretion induced by starvation. Gut 31, 43-53. 